\title{
Doctors increasingly caught in crosshairs of counter-terrorism efforts
}

\author{
n Cite as: CMAJ 2018 July 30;190:E919. doi: 10.1503/cmaj.109-5636
}

Posted on cmajnews.com on July 11, 2018.

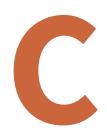

ounter-terrorism measures are increasingly intruding on the doctor-patient relationship, according to some physicians and human rights experts.

Doctors in the United Kingdom are pushing back against a program that obliges them to report anyone they suspect of holding extreme ideas to the authorities. The Prevent program applies to all public service workers, and the government has trained more than 400000 front-line staff to spot signs of radicalization. At a recent conference in Brighton, the British Medical Association moved to support physicians who refuse to participate in the program.

Doctors at the conference said the Prevent program sows fear and distrust, and leads to racial profiling. Muslims are 40 times more likely to be flagged under the program, noted Dr. Jackie Appleby. "Prevent makes us suspicious of each other," undermining the doctorpatient relationship, she said. "We depend on building trust."

A member of the association's armed forces committee argued that the program "keeps us all safe," but other delegates said it's unclear if that's true. Some 7631 people were flagged in 2015-16, but there was no action on most reports.

Meanwhile, governments increasingly use counter-terrorism laws to punish health workers for treating terrorists or other enemies. "It is alarming to see that more and more health providers around the world face threats for doing

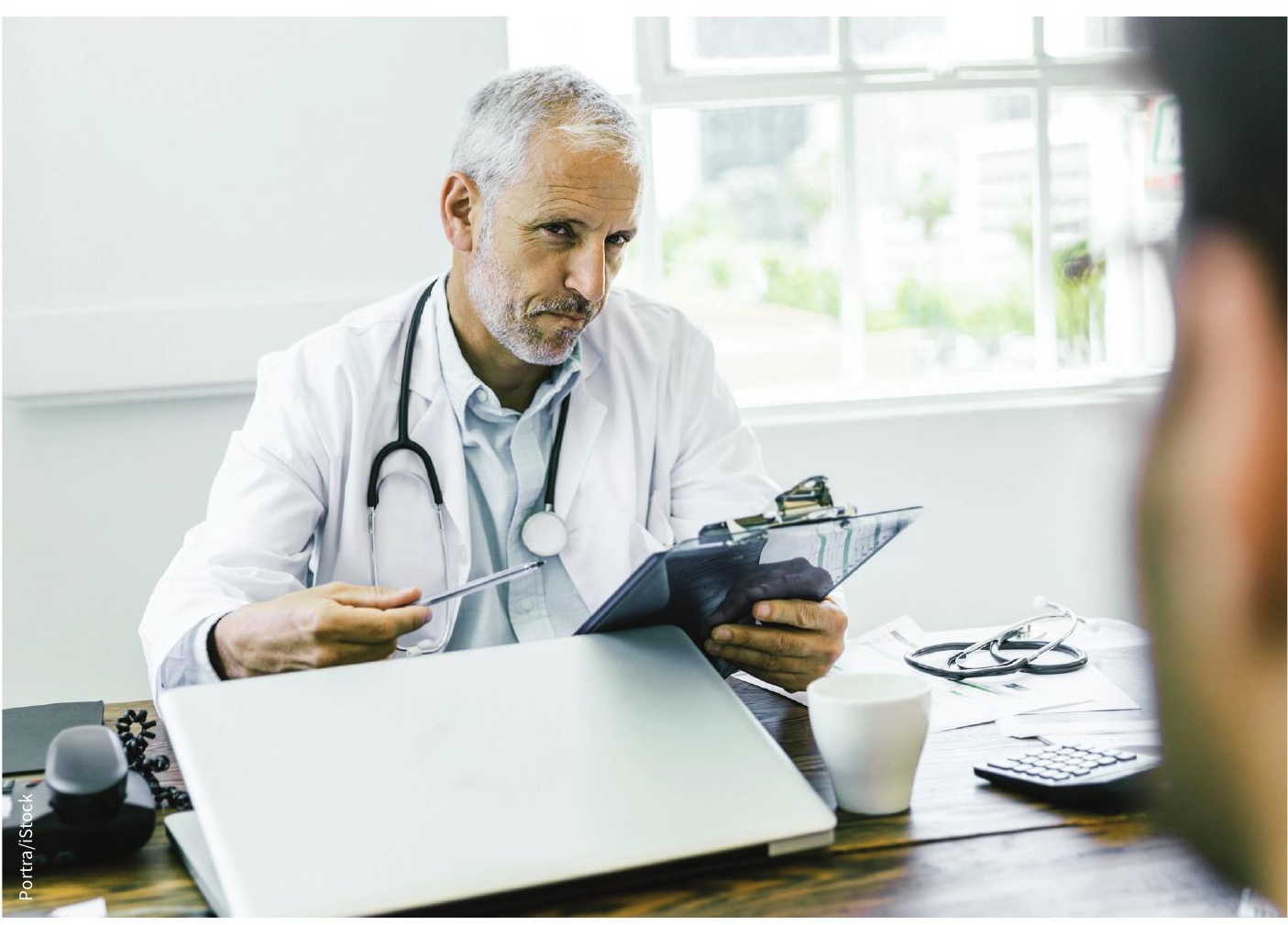

Should doctors be obliged to flag patients who they suspect hold extreme beliefs?

their jobs," according to Dr. Dainius Puras, United Nations special rapporteur on the right to health. A report commissioned by Puras reviewed laws and actions against health workers in 16 countries, including the UK, the United States and Australia, and found problems in all.

Counter-terrorism laws are often vague and too broad, stated the report. As a result, providing medical care, advice or supplies can be interpreted as providing "support" for terrorism. This has led to prosecution of health workers in some countries, including the US and Australia. In other nations, health professionals who treat alleged enemies of the state face administrative sanctions, harassment, intimidation and detention.

The report recommends that countries amend their laws to state explicitly that "the provision of medical services, or acts in support of such services, to wounded and sick individuals may not be subject to criminal or other sanctions." It also calls on the United Nations to include the protection of the medical mission and the delivery of health care in its resolution on the protection of human rights while countering terrorism.

Lauren Vogel, CMAJ 